\title{
SURVIVAL AND LONGEVITY OF FAMILY BUSINESSES: A CASE OF EASTERN BUSINESS CULTURE
}

\author{
Ravindra Hewa Kuruppuge, Ales Gregar
}

\section{Introduction}

Family businesses all over the world are suffering from long-term survival problems (Miller et al., 2004; Salvato \& Leif, 2008) despite financially outperforming in the short run (Dyer, 2006; Villalonga \& Amit, 2006). Meanwhile, general business literature agrees that if a business outperforms in accumulating more resources in the short run, it has a greater propensity to sustain in the long run (Efrat \& Shoham, 2012). In this case, despite the diverse ideologies, the short term in this paper is termed to be less than three years. The simple question arising from these two research findings is why family businesses are not as sustainable in the long run if they can outperform in the short run? Adding to this issue, McPherson (2010) mentioned that irrespective of the business type, family or non-family, businesses in general have a challenge to sustain and survive in any given time period. Further, Efrat and Shoham (2012) have noted that in the competitive market place, outperformance of any type of business (family or non-family) over their competitors in the short run does not guarantee business survival in the long run.

One probable reason for these discrepancies is based on the definitions of 'short run' and 'long run.' If previous studies utilized different definitions of these terms, it could have led to the conclusion that family businesses are unable to sustain in the long run while outperforming in the short run. If, on the other hand, researchers used the same precise definitions, then the reason for the discrepancy must be sought out elsewhere. Yet, according to Stafford et al. (2010), previous family business studies have generally failed to adequately define the terms short and long run. Another reason for the discrepancies might be based on a feature which is significant to both family and non-family businesses. When it comes to family businesses, family involvement has been identified as a significant feature which renders family businesses unique (Le BretonMiller \& Miller, 2009). Family involvement in the business is defined as engagement in business activities by members of the founding family of the business in levels of responsibilities such as employees, managers, governors and owners (Harms, 2014). Meanwhile, Hiebl (2015) is of the opinion that family involvement plays a highly beneficial role. Few studies have indicated that family involvement is a long term business survival problem (Lubatkin et al., 2007). Instead, most studies prove that family involvement contributes to shortrun outperformance over similar non-family businesses (Memili \& Misra, 2015). At this point, it might be concluded that family involvement in family businesses can lead to outperformance over non family businesses in the short run but cannot contribute to long-run sustainability. Yet, this may not be the truth.

Existing studies of family business survival has been able to explain the effects of family involvement on the longevity of the business (Anderson \& Reeb, 2003; Miller \& Le BretonMiller, 2006), but most such studies have been conducted in Western, developed business cultures. Few studies have been devoted to understanding the contribution of family involvement to business survival in Eastern developing business culture (McPherson, 2010). It is necessary to study family involvement and family business survival together to fully understand family businesses, as many businesses in Eastern business culture are managed as SMEs or privately-held family businesses (McPherson, 2010). For this reason, this study fills a niche in the current literature by focusing on how family businesses survive over long periods in Sri Lanka. In doing so, it increases the understanding of how family 
members become business partners and use their individual experiences and talents to improve the family business's chances for success.

\section{Study Context (Sri Lanka) and Literature Review \\ 1.1 Study Context}

Sri Lanka is a republic with a population of 20.1 million and a welfare economy. World Bank in its report recognized Sri Lanka as, "It was one of the first developing countries to understand the multidimensional nature of poverty, and has strongly emphasized policies aimed at promoting free health and education as early as the 1930s" (World Bank Report, 2000 , p. 27). Maintaining of a good economic growth (average rate is 6.3 percent between 2002 and 2014) in Sri Lanka has secured the fastest in South Asian countries during the last couple of years. Gross Domestic Product has occupied 7.8 percent in the year 2014 (Annual Report of Central Bank, 2014). GDP per capita increment is reported from USD 859 in 2000 to USD 3,256 in 2013. At the same time, the contribution of service sector of Sri Lankan economy is reported higher (more than 50 percent) and in that the contribution of businesses has accommodated more than 25 percent.

As a South Asian country, Sri Lankan management and business practices developed in a rich cultural heritage across 2,500 years and has been taken care largely by teachings of the Buddha (Ranasinghe, 2011). Till 1505, Sri Lanka was an independent state with agriculture as the predominant economic activity. Chandraprema (1989) mentioned that engaging in business activities in this time period was considered to be less socially acceptable. Only merchants from India, Arabia and China were the main traders who engaged in trade. Yet, this system started to change due to colonization of the country by foreigners. From the year 1505 till 1948 Portuguese, Dutch and British colonists ruled Sri Lanka (Jayawardena, 2000). The Dutch initiated the formal business practices in Sri Lanka with the establishment of the Dutch-East India Company. The Dutch were followed by the British who significantly influenced what Sri Lanka is today. The British converted Sri Lankan subsistence agricultural economy to a trading economy based on tea, natural rubber, coconut and spices. However,
Sri Lanka was awarded the independence in 1948. After the independence, the year 1977 was a remarkable turning point in Sri Lankan business and economic history (Athukorala \& Jayasuriya, 1994). In that year, Sri Lankan government made the decision to liberalize her economy and trade in order to increase exports of products of non-traditional firms and private sector organizations by giving a large number of financial and non-financial benefits. At present, Sri Lanka has become a welfare economy with the same status of business, commerce and management practices implemented in 1977. With all these changes, the country had gradually lost her indigenous identity of business and management because of practices of local people towards adapting western based management and business concepts (Nanayakkara, 2004). Mixing the local business and management practices with western management and business theories created moderated firms in the Sri Lankan business history.

However, Chandrakumara (2007) mentioned that current Sri Lankans tend more to embrace Eastern characteristics than Western in their social and family behaviors. The Sri Lankan family, under ideal condition, is limited to members of a single extended multi-generational family. Through the family relationship, members of a family share economic and social physiological security as well as the conflicts \& anxieties of other members (Jayawardena, 2000). Yet, the private sector of Sri Lanka has adapted its business tradition from mercantilist functions of the colonial private entrepreneur. As a result, rich history and tradition of strong family ties have made a special type of local business which can be named as 'Sri Lankan family businesses'. Family businesses in Sri Lanka have long been considered as a part of the culture. Initially these businesses centered the business on three major plantation crops (tea, coconut and rubber) with a bias toward trade, commerce, and services (Jayawardena, 2000). Gamage (2004) affirmed that some of such firms are still running as SMEs. And, Nanayakkara (2004) believed that managerial positions of most of these firms are largely reserved for technically competent family members and the behavior of individual firm is highly influenced by families. However, majority of such firms which were preliminary based on family ownership have 
become dominated and leading firms in private sector in present day in Sri Lanka.

\subsection{Literature Review}

\section{Family Businesses}

Even though a considerable amount of research attempts have tried to define family business, no research has become successful in bringing universally acceptable definition for family business (Klein, Astrachan, \& Smyrnios, 2005). In general, family business implies a business which is partly or fully managed by people appointed based on blood or relative relationship. Moving beyond the general definition, this study treats family business as a business which few or more family members with blood or relative relationship have management, governance \& ownership responsibilities and at least more than one member from the founding family bear the strategic level decision making power in a position like Chief Executive Officer, General Manager, founder or chief executives (Kellermanns et al., 2012). At this point, considering the most recent definitional approaches, scholars of family business have agreed upon two significant key concepts about family business. Firstly, family businesses are not consistent with each other (Sharma, 2004; Chrisman, Chua, \& Sharma, 2005). Secondly, all family businesses have interaction of the business entity, the family unit, and its individual members (Habbershon \& Williams, 1999). As a result, family businesses put into two descriptions. Businesses which primarily focus on achieving non-financial objectives through value creation is identified as lifestyle family business as their main purposes denotes providing jobs to family members and stabilizing family ties (Chrisman, Chua, \& Litz, 2003). Enterprising family businesses which is the other type entertain wealth creation through entrepreneurial and management actions recognizing prospects of long-term vision with key stakeholder's objectives (Chrisman, Chua, \& Litz, 2003)

Hence, in an overview of family and nonfamily businesses provides some general characteristics of family business over non family firms. Features like family ownership, management \& governance, succession, family involvement, family shareholding structure and level of control by a single or multiple family/ies provide the needed background to family businesses over non family businesses
(Hernández-Trasobares \& Górriz, 2015). Further, veteran researchers in this field suggest that family business should consist with significant features like ownership \& management right, succession \& power transfer operations, and a team between relative and non-relative (Chua et al., 1999; Habbershon et al., 2003; Nicholson, 2008). Moreover, as family members control the business, decisions regarding ownership and management right are all affected by family blood or relative relationship (Gersick et al., 1997). These ownership and management rights are obliged to transfer among generations. Succession and power transfer characteristics also make family business totally different to non-family business.

Such significant characteristics of family businesses create a unique systematic condition in the area of business performance. Depending on the context, some features constitute competitive advantages and some others may lead to diminish performance outcomes (Habbershon, Williams, \& MacMillan, 2003). Further, family business performance is mainly identified as a function of 'familiness'. Habbershon, Williams and MacMillan (2003) referred 'familiness' as a peculiar bundle of resources and capabilities resulting from the system interactions. It is the term used to emphasize those relations among family members, the business and the community at large. Those relations are meant to have the potential to create competitive advantage or disadvantage for the business which create uniqueness to family business. Based on the above argument, the author of this study is in the opinion that the family social system interaction is based on the owning family and such interaction enables the business to make significant performance outcomes.

\section{Business Survival Duration}

In general, all the businesses are trying to survive first and to succeed in the future. Yet, the span of life of businesses varies on various reasons. According to Van Praags (2003), survival duration implies the survival time of the business. This study treats survival duration as number of years a business carries out its activities in the society. However, survival of the business and success are different aspects of business performance and predictors of survival have no relation with success. Similarly, Kalleberg and Leicht (1991) mentioned that 
large scale businesses have more tendencies to survive, but small scale businesses are able to gain more profits. As a result, family business literature has consisted with business failure research studies than survival. Those few studies about family business survival still have shown their inability to identify family involvement as a factor of survival (Winter et al., 2004). Yet, some of factors of survival duration of family businesses are shown by family business literature.

Previous studies have entertained a large number of factors in relation to survival duration of family business. When general businesses are concerned, institutional theory suggests attractive macroeconomics factors with enabling organizations allow businesses to run longer (Porter, 2008). Similar to intuitional theory, organizational theory reveals that corporate leadership becomes the main determinant of long term business survival (Minztberg, 2007). When earlier family business are concerned internal business environment factors like the strategy that the firm pursues, its capital structure, the age of its owners, the ethnicity of the family, the structure of the family among others and external business environment factors like the level of political stability in the country, the level of macro-economic stability, the literacy rate in the country, the life expectancy rate have become prominent (Efrat \& Shoham, 2012). The model, known as the Olson circumplex model (Olson, 1986) reviewed a combination of two dimensions, the degree of cohesiveness and adaptability of family as main factors of survival duration of family business. The 'familiness' concept (Habbershon, Williams, \& MacMillan, 2003) is also identified as a positively correlated factor for the survival of the business. When exiting knowledge about family business survival determinants are concerned, studies have mainly given attention to three main systems. System of values and norms linked to family life, life of the business and external environment (Antheaume et al., 2013). Yet, analyzing their detailed research about family business, Sorenson et al. (2004) concluded that family involvement in and control of the business is associated with longer survival of family businesses.

\section{Family Involvement in Businesses}

The involvement of family in the business takes place through governance, ownership and management (Chrisman et al., 2005). Research studies in management, organization, and business studies have commonly identified the family of a business as a major factor to understand organizational behavior (Sharma, 2004). Researchers in family business generally agree that family involvement in the business is what makes the family business different from non-family business (Miller, 1983). Further, researchers agree that family involvement lead to typical business goals, behaviors, and performance results even among family firms (Chrisman, Chua et al., 2005; Dyer, 2006).

Family involvement in management makes family businesses different from non-family businesses. This differentiation mainly occurs as members from owner family involve in strategic and operational decision making process of the business (Le Breton-Miller \& Miller, 2009). Family involvement describes influence of the member of the owner family in managerial decision making and operational activities in functional areas of the business. In addition to business operational involvement, researchers have identified family involvement in business governance and ownership (Chrisman et al., 2003; Klein et al., 2005). Further, some studies have emphasized family involvement as workers in non-managerial positions (Kuruppuge, 2013). Yet, many empirical research evidences in family businesses suggest that family involvement in operational activities is more important than the other involvement activities such as ownership and governance (Chrisman et al., 2005). Family involvement in operational or management activities explains the way of carrying out duties and tasks by the family members of the owning family to achieve objectives of the business as top, middle and lower level managers of the business. Such contribution can be further viewed in long \& short period of time and strategic, functional and operational level decision making.

Previous studies about family involvement have mainly used agency, stewardship and resource based view (RBV) theories as theoretical lenses of their study (Hiebl, 2015). When the use of three theories in family business researches is compared, RBV has been given less priority over the two theories. Many authors in family business research have brought agency theory as a theoretical rigor for their studies. This has happened as agency theory approaches about intra-organizational 
processes from an economic perspective and it generally refers to the various ways that agents of a firm can influence the economic and non-economic outcomes and behaviors of the firm (Fama \& Jensen, 1983). In the other way, this theory explains the conflict of interest between an agent who acts as a representative of a principal and owner of the principal (Eisenhardt, 1989). However, many authors who used this theory in their study are in an opinion that family members reduce agency cost to the business (Chrisman et al., 2005). Further, they argue that family firms prefer family members as managers than non-family members as family managers working in the business associated with multitude benefits providing agency benefits (Danes, Stafford, Haynes, \& Amarapurkar, 2009). At the same time, uses of stewardship theory for their study highlight that family members provide various resources like human, financial \& social capital and capabilities like commitment, loyalty, trustworthiness \& firmspecific tacit knowledge (Kuruppuge, 2015). In contrast to agency theory, stewardship theory suggests that agents' (managers) interests about the business are aligned with owners of the business. This is taken place as interests of family managers unlike non-family managers are directed towards organizational objectives rather than managers' personal objectives (Davis et al., 1997). Further, this theory explains family managers have intrinsically motivated and have a deep emotional engagement with the business as their fortune, personal happiness, and reputation are highly related to performance of the firm.

\section{Research Methods}

In a study of family involvement in businesses; the business, time period, family and individual members are important aspects. All these concepts are contextual and subjective as the boundaries of the business, family and individual member depend on social background. Therefore, research approach for this study is explorative and inductive using qualitative methodologies. Multiple case-study method was used as the strategy of inquiry. It permits the researcher to strive towards understanding the phenomenon of interest by using several independent instrumental case studies to get an insight in the study area.

\subsection{Instrument and Data Collection Procedure}

The author of this study was able to conduct twenty two interviews. Initially, author wanted to conduct twenty four interviews with respondents from twelve family firms. But interviews were limited to twenty two as two owners of selected cases refused to provide information due to personal reasons. Yet, twenty two interviews comprised with 12 interviews with senior family managers and ten interviews with family business owners. Seventeen interviews were conducted in person and five interviews were done over the phone. All interviews took place in June to September, 2015. Seventeenth respondents allowed recording the interview digitally. For the remaining, the interviewer noted the main points while the interviews were in process and obtained some additional important notes of the conversation immediately after the interview. All interviews in person took place in the business premises of the respondent. Interviews over the phone lasted 20-35 minutes while others took average 45 minutes. Interview guide with semi-structured open ended questions were directed to the interview. Each respondent was interviewed separately so as to make the environment enabling each participant to express their views without influence. While four interviews handled in Sinhalese (local language), all others were conducted in English. The author could handle both English and Sinhala sufficiently. Interview guide for business owners and managers comprised with five main semi-structured questions. The main points of the questions were; historical development of the business and family involvement, current nature of family involvement, benefits of family involvement, drawbacks of family involvement and business survival techniques.

\subsection{Sampling Description}

All the cases and respondents were selected using purposive sampling strategy. Since the unit of analysis of this study is an individual case, family business firms were selected carefully. Family firms that represented family members from two generations from the founding owner's generation (minimum thirty years existence) and privately held (non-listed) family firms were considered as requirements to select as cases for this study. Nine out of twelve firms were oriented in products and three oriented 


\section{Ekonomika a management}

in both products as well as services. Financial outcomes of most of the cases indicated either good or average performances during the last couple of years. Firms were operating in different industrial sectors such as agricultural machinery product and development, hotel and restaurant, sweets and bakery products, leather products, furniture products and marketing, jewelry, biscuits related products, textiles, optical, assets development, book publication and selling and retail businesses (supermarkets). All cases were located in Western Province in Sri Lanka while six cases in Gampaha, four cases in Colombo and two cases in Kalutara Districts. Western Province consists of three Districts namely Gampaha, Colombo and Kalutara is considered as the highest industrialized province out of nine Provinces in Sri Lanka. Respondents, both business owner and managers had at least eight years or more experience in their position to the year 2015. All the managers in the sample were highly active personalities in day today activities in the business. Their positions in the business were varied. Five out of twelve were head of a section (operations, human resources, marketing). Three represented the position of factory manager and another two out of twelve were consultant to business operations. Remaining two family business

\begin{tabular}{|c|c|c|c|c|c|}
\hline Case no. & Industry & $\begin{array}{l}\text { Location } \\
\text { (District) }\end{array}$ & $\begin{array}{c}\text { Interview } \\
\text { no. }\end{array}$ & $\begin{array}{c}\text { Type of } \\
\text { respondents }\end{array}$ & Interviewed \\
\hline \multirow[b]{2}{*}{1} & \multirow{2}{*}{$\begin{array}{l}\text { Agricultural machinery product } \\
\text { and development }\end{array}$} & \multirow[b]{2}{*}{ Gampaha } & 1 & owner & yes \\
\hline & & & 2 & manager & yes \\
\hline \multirow{2}{*}{2} & \multirow{2}{*}{ Restaurant and catering } & \multirow{2}{*}{ Kalutara } & 3 & owner & yes \\
\hline & & & 4 & manager & yes \\
\hline \multirow{2}{*}{3} & \multirow{2}{*}{ Sweets and bakery products } & \multirow{2}{*}{ Gampaha } & 5 & owner & yes \\
\hline & & & 6 & manager & yes \\
\hline \multirow{2}{*}{4} & \multirow{2}{*}{ Leather products } & \multirow{2}{*}{ Gampaha } & 7 & owner & no \\
\hline & & & 8 & manager & yes \\
\hline \multirow{2}{*}{5} & \multirow{2}{*}{ Furniture } & \multirow{2}{*}{ Colombo } & 9 & owner & yes \\
\hline & & & 10 & manager & yes \\
\hline \multirow{2}{*}{6} & \multirow{2}{*}{ Jewelry products } & \multirow{2}{*}{ Kalutara } & 11 & owner & yes \\
\hline & & & 12 & manager & yes \\
\hline \multirow{2}{*}{7} & \multirow{2}{*}{ Biscuits related products } & \multirow{2}{*}{ Colombo } & 13 & owner & yes \\
\hline & & & 14 & manager & yes \\
\hline \multirow{2}{*}{8} & \multirow{2}{*}{ Textiles } & \multirow{2}{*}{ Gampaha } & 15 & owner & no \\
\hline & & & 16 & manager & yes \\
\hline \multirow{2}{*}{9} & \multirow{2}{*}{ Optical products } & \multirow{2}{*}{ Gampaha } & 17 & owner & yes \\
\hline & & & 18 & manager & yes \\
\hline \multirow{2}{*}{10} & \multirow{2}{*}{ Assets development } & \multirow{2}{*}{ Gampaha } & 19 & owner & yes \\
\hline & & & 20 & manager & yes \\
\hline \multirow{2}{*}{11} & \multirow{2}{*}{ Book publication and marketing } & \multirow{2}{*}{ Colombo } & 21 & owner & yes \\
\hline & & & 22 & manager & yes \\
\hline \multirow{2}{*}{12} & Sunermarkets & Colombo & 23 & owner & yes \\
\hline & Supentiáneto & 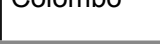 & 24 & manager & yes \\
\hline
\end{tabular}


managers (respondents) had unclear position but they overseer all business and administration activities. Seven females (two business owners $\&$ five managers) and fifteen males attended for the interview as respondents. A summary of the sample and interviewees is given in Tab. 1 .

\subsection{Method of Data Analysis}

Interviews were digitally recorded and main points of non-recorded interviews were transcribed in English in respondent's pauses. Interviews conducted in local language were translated into English by the author of the study. Transcriptions included incomplete statements, emotions expressions by words and errors in sentences as in the same way participant express in interviews. Then, MS-Word transcribed text files (22) were copied to Atlas.ti 7 software for coding the themes. Codes generated by the software were used to identify sub themes manually. Content analysis helped to identify patterns of family business involvement in the event of running a business in the long term.

\subsection{Reliability of the Study}

Reliability of this type of research means that the process of the research is reasonably consistent over time \& across research studies and methods (Miles \& Huberman, 1994). The main purpose of maintaining reliability of a qualitative study is to reduce errors and biases in research design, data collection, analysis of data and reporting the findings of the research study. In order to maintain the reliability, the researcher designed this study as a multiple case-study as the strategy of inquiry. That allowed triangulation of data collection and sources such as interviews and document reviews in different settings (Yin, 1994). One case serve as unit of analysis, emerging themes of the study phenomena, conclusions and findings reflect viewpoints of different personalities. A single case represents opinions of two persons (owner and a manager). In order to maintain reliability of data in interviews, coding by multiple people (Duriau, Reger, \& Pfarrer, 2007) and inter-corder reliability test were performed (Stemler, 2001). A university lecturer from University of Peradeniya, Sri Lanka who has well trained in qualitative research conducted the second coding for the study. The result of content coding by the first coder (author) and the second coder of the same themes and sub themes of twenty two transcriptions were matched around 80 percent. Accordingly, the coding system implemented in the study can be treated as reliable enough to make conclusions.

\section{Results and Discussion}

The analysis of interview data was begun after coding and categorization. Four main themes on family involvement emerged from the data; namely self-motivation, motivation from family, self-success and self-success through business success. In this analysis, coding was possible in more than one subtheme. If interviewee mentioned several subthemes, each one was considered as separate answer.

\subsection{Self-Motivation}

This study focuses on understanding how family businesses experience of family members involved in the business in the event of running the business long period in Sri Lanka. All respondents from nine out of twelve cases agreed that they are self-motivated to engage in businesses. This has clearly replicated the stewardship behavior of managers of family businesses of which explained in stewardship theory (Tosi et al., 2003). Almost, all respondents supported this view believing that individual survival is dependent on the business. Especially, business owners paved their great enthusiasm in engaging activities in businesses. At the same time, managers from owning family also showed their self-motivation to engage in business activities as same as owners. One of the owners mentioned:

"This business is everything ...this is what we got from our father... we, as a family are dependent on this business..." (Interview 17, case 09, owner).

One family manager of the business emphasized the same idea in different way. Even in the interview, he was so optimistic towards dedication of employees. He said everybody works together without considering family relations to achieve business objectives. He further elaborated:

"Hmmm... I am enjoying the job and responsibilities... I have a dream to make our business as the best business in Sri Lanka." (Interview 18, case 09, manager).

Some other family managers discussed about their motives of joining, retaining and retiring from the current business. Most 
family managers have obtained their degree or equivalent professional qualification from reputed organizations in the World. Four out of twelve managers have obtained master's Degree in business administration and eight of them have obtained first degree either in Management, Engineering, Science or Arts. Four of them have studied abroad. One manager explained about his education and its relevance to business:

"I obtained my MBA eight years back and now I have fifteen years' of experience in this field. The salary as a figure that I am getting from this business is less than the market value of such a person like me... But the other benefits and self-satisfaction by working in this company cannot be valued by money or figures. I will never be motivated somewhere else like I work in this company. Even if another company offers me a million rupees per month which is ten times of my present salary, still I will remain in this company..." (Interview 02, case 01, manager).

When owners are concerned, five out of ten have obtained a Degree or an equivalent qualification. Especially, when cases like 01, 03, 05, 07, 09, 10, 11 and 12 are considered, both owners and managers have well equipped in formal education and professional qualifications. Owner of cases 01, 11 and 12 elaborated the following:

"I am an engineer by profession. I was trained by my parents to take over this business one day." (Interview 01, case 01, owner).

"I have two sons; both of them are studying abroad. Once they come back after their studies, they will assist me..." (Interview 19, case 11, owner).

"...all managers are required to obtain at least a professional qualification if they can't study for a Degree..." (Interview 23, case 12, owner).

According to respondents, it was clear that the previous generation handled the business having a plan in their mind to transfer the business one day in future. Accordingly, they have prepared their next generation providing appropriate education to face business challenges in future. As a result, most owners and managers of family businesses have obtained a Degree or an equivalent professional qualification. On the other hand, the level of education and the area of study have motivated owners and managers to perform well in the business. These conclusions related to family businesses in Eastern business culture are in contrast to the common agreement among family business researchers. Family business literature in Western business culture believes that family businesses do not promote professionals in their business as they always give priority for kingship than professional qualifications (Sharma \& Irving, 2005). Instead, earlier generation of Sri Lankan family businesses have given proper education and practical training to business successors to take over their businesses. They have trained their own managers to take business decisions professionally.

Prevailing business challenges also have motivated owners and managers to engage in the business activities. Both managers and owners consider business challenges as their personal challenges. Especially, they become more aggressive to compete with similar businesses of which their businesses are challenged. One respondent from case 05 explained:

"You know that some people who left our company have started another similar plant. They produce low quality products for low price. They try to approach our customer base. We never allow anybody to mislead our customers until this company does exist." (Interview 09, case 05, owner).

The manager of the same case elaborated the departure of a partner very emotionally from their business:

"...that person destroyed both business and family... we will see who will win the game..." (Interview 10, case 05, manager).

Kinship plays an important role in case of self-motivation of family members who are currently engaging in the business. Family members who have very close relationship to business owners are motivated to work much harder than others. This was further revealed by body language of some of the respondents when they express their opinions. Further, most of the time, almost all respondents name their business as 'our business', 'father's business', 'mother's business, 'our family business'. The researcher observed that most of the family members who are working as managers were siblings of owners of the business. At the same time, if the business is owned by multiple owners, they were from the same nuclear family (brothers and sisters). That may have impacted 
to both owners and managers to make selfmotivated to engage in family business.

In summary, according to respondent's views, family members are mostly selfmotivated to join and work in family businesses. This is clear reflection of theoretical explanation of stewardship theory. The stewardship theory explains that family managers behave in the firm in a way of dedicating their personal interests for the benefit of business as members believe that cooperative and collective behavior make positive business outcome (Gomez-Mejia et al., 2007). Further, interviewees mentioned that family members become self-motivated to join and work in family business because of three reasons. Education and experience of members of the family, prevailing business challenges and kinship to owners of the business are dominant reasons which emerged from interviews conducted with family managers and owners of family business in Sri Lanka.

\subsection{Motivation from Family}

In addition to self-motivation, the families of respondents have made their members motivated to work in the business. This is a clear reflection of extrinsic motivation explained in agency theory (Fama \& Jensen, 1983).

"My parents had a dream to start four similar plants separately for four of us. My father could not achieve it in his life time. But, my mother is still expecting that to happen in her life time and she is forcing us." (Interview 08, case 04, manager).

As reflected by interviews, most of the owners and family managers have pushed and motivated directly by their respective families. Mainly this takes place in family businesses as most of the family requirements of the owning family are fulfilled by the business. And family members of extended family expect nonfinancial objectives such as job opportunities for family members from the business. As a result, case 03 had employed around twenty family members. Some of them are working in nonmanagerial positions like cashier, store keeper. At the same time, one respondent from case 12 mentioned:

"...hmmm... we have twelve very close family members as managers. Four of them represent the directorate of the business..." (Interview 24, case 12, manager).

Family has motivated members indirectly as well. According to the respondents, one of the interesting ways is transferring the tacit knowledge of business to selected members who are engaging in the business.

"...my father did not consider me as a typical daughter ... he gave me enough knowledge and secrets about the business. Actually, that knowledge sharing helps me a lot to make decisions even now..." (Interview 16, case 08, manager).

When the required tacit knowledge is transferred to a member, he or she is highly motivated to protect the knowledge and to use it in the business. As business secrets are highly protected among very close family members working in the business, knowing business secrets is also considered as a special privilege. The researcher observed that those members who know business secrets and tactics of the business have more chance to be the Chairman or CEO of the business in the succession process.

Further, interviewees mentioned about success stories of the founder and other dedicated family members in the past. Those stories have made present family members motivated to work in the business. Most of the time, current family members pass these stories to next generation and even to other employees. At the same time, when an event like family gathering is taken place, members share their experiences and compare those with the previous generation and the current generations. However, those success stories have made family members motivated engaging in the business.

"My grandparents have worked continuous three days without sleeping... at the beginning of the business. And they have walked... door to door...to sell these sweets" (Interview 05, case 03 , manager).

In summary, according to respondent's views, respective families have motivated family members to join and work in family businesses. This is a clear reflection of theoretical explanation of agency theory which appears as extrinsic motivation. Families motivate their relatives to join and work in the business because of three reasons. Directly, family requirements have made family members motivated. And indirectly, tacit knowledge and success stories of the business have also motivated family members working in the business in Sri Lanka. Both self-motivation and motivation from family have been identified 
as emerging themes of family firms in Western business culture as well. Yet, emerged sub themes are quite new and specific to Eastern business culture like Sri Lanka. However, these outcomes facilitated to understand "how family members become partners of business and family member's experiences' which is the first objective of the study.

\subsection{Self-Success}

In general, people pursue their own success. They may have varied definition for selfsuccess. Interviewees' responses of this study indicated self-success as a measure of living standard and social recognition of the society. These two concepts which came out from family members' involvement in businesses are highly related with the business functions. Respondents considered living standard as 'what they consume as tangible and intangibles goods and services at a time'. Sometimes, family members could not differentiate business success from self-success since they treat them as equal. If family members consume higher amount of goods and services personally, they treat sometimes that as a business success. However, family members believe in business success than self-success as business success and self- success are interdependent. A manager from case 11 mentioned:

"Whatever we have at the moment, lands, buildings, houses, vehicles, etc.... is a result of our business. So... life has become a part of the business." (Interview 11, case 22, manager).

In contrast to this, all respondents from case 06 and 07 considered the business as a challenge for their personal life. They complained that they have to dedicate all personal happiness for the business. Their expressions showed that some family members have better life over the facilities of the business. But those family members had shown poor contribution to the business.

"...I have no time to spend with my kids... I am so frustrated with that..." (Interview 11, case 06 , owner).

"Some family members do not work hard. So... instead, I have to attend for all of their jobs. They are privileged to be managers in the business enjoying their life...we cannot question them. CEO is always protecting them..." (Interview 14, case 07, manager).

The other part of self-success considered by respondents is social recognition. They view social recognition as part of the business. All interviewees of ten out of twelve cases implicitly or explicitly mentioned that they expect others respect and they wanted to be a member of a different family business. Most of them are enjoying when they are called by Chuuti/ loku mahathaya (sir), baby mahaththaya (sir), loku I podi nona (madam) and baby nona (madam) by people even from outside the business. Yet, both respondents from case 07 had a different view on that.

"...l normally spent more than one lakh per month for unnecessary social activities." (Interview 13, case 07, owner).

In summary, according to respondent's views, family members expect self-success by consumption of tangible and intangible artifacts and by attaining to social respect. When respondent's views are further concerned, it is obvious that family member's self-success is dependent on business success. In the other way, business success is also dependent on success of family members. However, these interdependencies have made ultimately positive effects to family and business. As a result, the business has been able to enjoy its longevity.

\subsection{Self-Success through Business Success}

As explained under the self-success theme, both family members individual success and business success is interdependent. Therefore, family members in the business are intrinsically motivated to protect the business in the long run as it relates to their personal life. In addition to matters briefed under the theme of selfsuccess, there are some other expectations of family owners and managers emerged in the interviews. Respondents from eleven out of twelve cases agreed that networking of new people, fulfilling urgent requirement of family and protecting the business name over generations are main concerns for them to make the business a success. As a result, family members strive to protect and develop the business.

"...When we expand our business, our network with other business people and customers are also increased. Simultaneously, we create our own network..." (Interview 04, case 02 , manager).

"This business name must remain in Sri Lanka at least another hundred years..." (Interview 03, case 02, owner). 
The analysis of responses indicated that most family members, regardless of their positions, are trying to make their business a success in the long run. This happens basically as family members' personal and family requirements are tightly connected with business performance. In order to be successful in their personal life and personal achievements, they strive to make the business a success. As a result, as explained by Fama and Jensen (1983), agency cost which occurs due to asymmetry of information between owners and managers of the business can be decreased in the firm. Ultimately, the business could enjoy its longevity.

In summary, according to respondent's views, family members expect self-success through business success. Respondents consider business success as a great opportunity to make good networking of new people, fulfilling family requirements and protecting the business name over generations. When family members attempt to achieve above objectives, the business can make its life span longer. The second objective of this study is to understand how business survival is facilitated and experienced by family involvement. The analysis of themes which came out from interviews, self-success and self-success through business success addresses the second objective of this study.

\subsection{Practical Significance of the Study}

Researchers in this field generally believe that most of the business firms in the world are run by families. This remains unchanged for Sri Lankan businesses oriented in Eastern business culture where most of SMEs are operated by families (Gamage, 2004). At same time, the economic landscape of most nations has been leveled by family firms (Astrachan \& Shanker, 2003). If so, understanding and clarifying family business related themes will immensely facilitate most of the business stakeholders who have businesses in Eastern business culture. Further, it will satisfy growing recognition of understanding of family involvement in business which is an essential concept for progress of family firms in the long run (Habbershon, Williams, \& MacMillan, 2003). Specially, since only a small number of family businesses survive to the third generation (Miller et al., 2004), such contribution is of practical value to new and emerging family firms.

\subsection{Limitations of the Methodology}

General limitations in qualitative research remain unchanged for this study as well. Inability to generalize findings of this study to a larger community is one of the main limitations. Generally, qualitative researches are not meant to generalize or compare findings. Main objective of this study was to understand the emerging themes of family involvement which commissioning of generalization is not required. Data from interviews served the purpose of understanding family involvement in the event of continuing businesses.

The limitation of subjectivity of the study was also addressed by adapting to several techniques. The author of this study is an expertise in qualitative research with enough experiences in handling interviews without bias. At the same time, conducting of interviews, translations of interview data, transcribing were done by one person (the author). It enabled to maintain the highest consistency in data sources. It was further strengthened in the process of conducting interviews with semistructured open ended questions guided by interview protocol.

\subsection{Suggestion for Future Research}

It would also be worthwhile for subsequent researchers to expand the research to include a broader sample representing all the provinces in Sri Lanka. Different geographical settings and contexts to determine how family involvement patterns differ from those analysed here would be of paramount important to understand business survival. Family run businesses in different cultural settings like Northern \& Eastern provinces, urban and rural areas in Sri Lanka, may indeed provide rise to different themes, which are deemed to be of greater importance within their cultural context and environment.

\section{Conclusion}

This study focuses on understanding how family businesses experience of family members involvement in the business in the event of running the business long period in Sri Lanka. Few noteworthy final points of the study can be noted here.

One point is that privately held family businesses in Sri Lanka have shown different concepts in contrast to known concepts of family businesses operate in Western business 
cultures. Studies developed in Western business culture argue that family businesses do not entertain professionals outside the family as their managers and qualified nonfamily managers are also kept away (Simon \& Hitt, 2003). As a result, these studies have concluded that family businesses are suffering from dearth of human capital (Chisman, Chua, \& Steier, 2005). In contrast, this study paved the way to understand that family businesses operate in Sri Lanka have not faced the same problem of dearth of human capital as like Western countries. Mostly business owners and managers of privately held family businesses in Sri Lanka professionally qualified to perform in their positions. Most of them are degree holders in relevant field and their education have motivated them perform in the position. Because of that, Sri Lankan family businesses are not suffering from skilled oriented human capital same as family businesses operated in Western business culture.

The other point is linked to the literature review in this study. Research studies developed in Western business culture have clearly divided family business as lifestyle and enterprising family businesses (Chrisman, Chua, \& Litz, 2003). This study has not come up with enough evidences about availability of enterprising family firms in Sri Lanka which entertain wealth creation through entrepreneurial and management actions recognizing prospects of long-term vision with key stakeholder's objectives. Almost all firms represented the category of lifestyle family businesses which primarily focus on achieving non-financial objectives through value creation and their main purposes denoted providing jobs to family members and stabilizing family ties (Chrisman, Chua, \& Litz, 2003). The lifestyle concept itself has created family members motivation to protect the business. Moreover, self-success of family members in the business and business success has become an interdependent to each other. This has resulted 'self-success through business success' in family businesses in Sri Lanka.

Several family involvement characteristics which assist directly and indirectly to the continuation of business emerged in the analysis. Ability of the business to satisfy family requirements, tacit knowledge transfer initiatives, social recognition of family members and competition among similar businesses have insisted family business to run the business long period. Overall, accomplishment of individual and family requirements of owning family through business activities has considerable role to play in case of business survival in privately held, successful family businesses in Sri Lanka.

Authors of this article are thankful to the Internal Grant Agency of FaME TBU No. IGA/FaME/2016/001: Enhancing Business Performance through Employees' Knowledge Sharing, for financial support to carry out this research.

\section{References}

Annual Report. (2014). Sri Lanka: Central Bank of Sri Lanka.

Antheaume, N., Robic, P., \& Barbelivien, D. (2013). French family business and longevity: have they been conducting sustainable development policies before it became a fashion? Business History, 55(6), 942-962. https://dx.doi.org/10.1080/00076791.2012.744583.

Astrachan, J. H., \& Shanker, M. C. (2003). Myths and Realities: Family Businesses' Contribution to the US Economy - A Framework for Assessing Family Business Statistics. Family Business Review, 9(2), 107-123. https://dx.doi.org/10.1111/j.1741-6248.1996.00107.x.

Athukorala, P., \& Jayasuriya, S. (1994). Macro-Economic Policies, Crises and Growth in Sri Lanka: 1969-1990. Washington D.C.: The World Bank.

Chandrakumara, A. (2007). Does HRM fit really matter to citizenship and task performance? Sri Lankan manufacturing sector experience. Employee Relations, 29(6), 611-639. https://dx.doi.org/10.1108/01425450710826113.

Chandraprema, C., \& Ruhuna, A. (1989). A study of history, society, \& ideology of Southern Sri Lanka. Colombo: Bharat Publishers.

Chrisman, J. J., Chua, J. H., \& Litz, R. (2003). A unified systems perspective of family firm performance: An extension and integration. Journal of Business Venturing, 18(4), 467-472. https://dx.doi.org/10.1016/s0883-9026(03)00055-7.

Chrisman, J. J., Chua, J. H., \& Sharma, P. (2005). Trends and directions in the development of a strategic management theory of the family firm. Entrepreneurship Theory and Practice, 29(5), 555-576. https://dx.doi. org/10.1111/j.1540-6520.2005.00098.x.

Chrisman, J. J., Chua, J. H., \& Steier, L. 
(2005). Sources and consequences of distinct familiness: An introduction. Entrepreneurship Theory and Practice, 29(3), 237-247. https:// dx.doi.org/10.1111/j.1540-6520.2005.00080.x.

Danes, S. M., Lee, J., Stafford, K., \& Heck, R. K. Z. (2008). The effects of ethnicity and culture on entrepreneurial experience: An extension of sustainable family business theory. Journal of Developmental Entrepreneurship, 13(3), 229-268. https://dx.doi.org/10.1142/ s1084946708001010.

Danes, S. M., Stafford, K., Haynes, G., \& Amarapurkar, S. S. (2009). Family capital of family firms: Bridging human, social, and financial capital. Family Business Review, 22(3), 199-215. https://dx.doi.org/10.1177/0894486509333424.

Davis, J. H., Schoorman, F. D., \& Donaldson, L. (1997). Towards a stewardship theory of management. Academy of Management Review, 22(1), 20-47. https://doi.org/10.5465/ amr.1997.9707180258.

Duriau, V. J., Reger, R. K., \& Pfarrer, M. D. (2007). A content analysis of the content analysis literature in organization studies. Organizational Research Methods, 10(1), 5-34. https://dx.doi.org/10.1177/1094428106289252.

Dyer, G. W. (2006). Examining the "Family Effect" on Firm Performance. Family Business Review, 19(4), 253-273. https://dx.doi. org/10.1111/j.1741-6248.2006.00074.x.

Efrat, K., \& Shoham, A. (2012). Born global firms: The differences between their shortand long-term performance drivers. Journal of World Business, 47, 675-685. https://dx.doi. org/10.1016/j.jwb.2012.01.015.

Eisenhardt, K. M. (1989). Building theories from case study research. Academy of Management Review, 14(4), 532-550. https://doi.org/10.5465/amr.1989.4308385.

Fama, E., \& Jensen, M. (1983). Agency problems and residual claims. Journal of Law and Economics, 26, 325-344. https://dx.doi. org/10.2139/ssrn.94032.

Gamage, H. R. (2004). Understanding the Social Realities of Entrepreneurial Performance in Sri Lanka: An Alternative Paradigm. Published Doctoral Dissertation, The University of Queensland, Australia.

Gersick, K., Davis, J., McCollom, M., \& Lansberg, I. (1997). Generation to Generation. Boston (MA): Harvard Business School Press.

Gomez-Mejia, L. R., Haynes, K. T., NunezNickel, M., Jacobson, K. J.L., \& Moyano-Fuentes, J. (2007). Socioemotional wealth and business risks in family-controlled firms: Evidence from Spanish olive oil mills. Administrative Science Quarterly, 52(1),106-137. https://doi. org/10.2189/asqu.52.1.106.

Habbershon, T. G., Mary L. W., \& MacMillan, I. C. (2003). A unified systems perspective of family firm performance. Journal of Business Venturing, 18(4), 451-465. https://doi.org/10.1016/S0883-9026(03)00053-3.

Habbershon, T. G., \& Williams, M. L. (1999). A resource-based framework for assessing the strategic advantages of family firms. Family Business Review, 13(1), 1-25. https://dx.doi. org/10.1111/j.1741-6248.1999.00001.x.

Harms, H. (2014). Review of Family Business Definitions: Cluster Approach and Implications of Heterogeneous Application for Family Business Research. International Journal of Financial Studies, 2(3), 280-314. https://dx.doi.org/10.3390/ijfs2030280.

Hernández-Trasobares, A., \& Górriz, C. G. (2015). Does Concentration of Ownership and Family Control Affect Specialisation/ Diversification Business Strategies? E\&M Ekonomie a Management, 18(4), 78-92. https://dx.doi.org/10.15240/tul/001/2015-4-006.

Hiebl, M. R. W. (2015). Family involvement and organizational ambidexterity in latergeneration family businesses: A framework for further investigation. Management Decision, 53(5), 1061-1082. https://dx.doi.org/10.1108/ md-04-2014-0191.

Jayawardena, K. (2000). No bodies to some bodies: Rice of the colonial Bourgeoisie in Sri Lanka. Colombo: Social Scientists' Association - Sri Lanka.

Kalleberg, A. L., \& Leicht, K. T. (1991). Gender and organizational performance: Determinants of small business survival and success. Academy of Management Journal, 34(1), 136-161. https://doi.org/10.5465/256305.

Kellermanns, F. W., Eddleston, K. A., Sarathy, R., \& Murphy, F. (2012). Innovativeness in family firms: a family influence perspective. Small Business Economics, 38(1), 85-101. https://dx.doi.org/10.1007/s11187-010-9268-5.

Kim, Y., \& Gao, F. Y. (2013). Does family involvement increase business performance? Family-longevity goals' moderating role in Chinese family firms. Journal of Business Research, 66(2), 265-274. https://dx.doi. org/10.1016/j.jbusres.2012.08.018.

Klein, S. B., Astrachan, J. H., \& Smyrnios, K. X. (2005). The F-PEC scale of family influence: Construction, validation, and further 
implication for theory. Entrepreneurship Theory and Practice, 29(3), 321-339. https://dx.doi. org/10.1111/j.1540-6520.2005.00086.x.

Kuruppuge, R. H. (2013). Family Involvement and Business Growth: A Study of Family Businesses in Sri Lanka. Unpublished MBA Thesis. Colombo: Colombo University, Sri Lanka.

Kuruppuge, R. H., \& Gregar, A. (2015). Pushing or pulling of the business by family members: a study of family businesses in Sri Lanka. Foundations of Management, 7(4), 121-128. https://dx.doi.org/10.1515/fman-2015-0030.

Le Breton-Miller, I., \& Miller, D. (2009). Agency vs. stewardship in public family firms: A social embeddedness reconciliation. Entrepreneurship Theory and Practice, 33(6), 1169-1191. https://dx.doi.org/10.1111/j.15406520.2009.00339.x.

Lubatkin, M. H., Durand, R., \& Ling, Y. (2007). The missing lens in family firm governance theory: A self-typology of parental altruism. Journal of Business Research, 60(10), 1022-1029. https://dx.doi.org/10.1016/j. jbusres.2006.12.019.

McPherson, M. (2010). Business practices within South Asian family and non-family firms. International Journal of Entrepreneurial Behaviour \& Research, 16(5), 389-413. https://dx.doi.org/10.1108/13552551011071878.

Memili, E., \& Misra, K. (2015). Corporate governance provisions, family involvement, and firm performance in publicly traded family firms. International Journal of Financial Studies, 3(3), 194-229. https://dx.doi.org/10.3390/ ijfs3030194.

Miles, M. B., \& Huberman, A. M. (1984). Qualitative Data Analysis: A Source Book of New Methods. Beverly Hills, CA: Sage Publications.

Miller, D. (1983). The correlates of entrepreneurship in three types of firms. Management Science, 29(7), 770-791. https://dx.doi.org/10.1287/mnsc.29.7.770.

Miller, D., Le Breton-Miller, I., \& Steier L. P. (2004). Toward an Integrative Model of Effective FOB Succession. Entrepreneurship Theory and Practice, 28(4), 305-328. https:// dx.doi.org/10.1111/j.1540-6520.2004.00047.x.

Miller, D., \& Le Breton-Miller, I. (2006). Family governance and firm performance: Agency, stewardship and capabilities. Family Business Review, 19(1), 73-87. https://dx.doi. org/10.1111/j.1741-6248.2006.00063.x.
Nanayakkara, G. (2004). Managing in Sri Lanka: Problems and Prospects. Volume II. Colombo, Sri Lanka: Public Administration and National Development, Academy of Management Sciences.

Nicholson, N. (2008). Evolutionary psychology, organizational culture, and the family firm.Academy of Management Perspectives, 22(2), 73-84. https://dx.doi.org/10.5465/amp.2008.32739760.

Olson, D. H. (1986). Circumplex Model VII: Validation Studies and FACES III. Family Process, 25(3), 337-351. https://dx.doi. org/10.1111/j.1545-5300.1986.00337.x.

Ranasinghe, S. (2011). Managing in a Developing Context: Sri Lankan perspectives. Hokandara, Sri Lanka: E-Team Designs.

Salvato, C., \& Melin, L. (2008). Creating Value across Generations in Family-Controlled Businesses: The Role of Family Social Capital. Family Business Review, 21(3), 259-276. https:// dx.doi.org/10.1111/j.1741-6248.2008.00127.x.

Sharma, P. (2004). An overview of the field of family business studies: current status and directions for the future. Family Business Review, 17(1), 1-36. https://doi.org/10.1111/ j.1741-6248.2004.00001.x.

Sharma, P., \& Irving, P. G. (2005). Four Bases of Family Business Successor Commitment: Antecedentsand Consequences. Entrepreneurship Theory and Practice, 29(1), 13-33. https://dx.doi. org/10.1111/j.1540-6520.2005.00067.x.

Simon, D. G., \& Hitt, M. A. (2003). Managing resources: Linking unique resources, management, and wealth creation in family firms. Entrepreneurship Theory and Practice, 27(4), 339-358. https://dx.doi.org/10.1111/15408520.t01-1-00013.

Stafford, K., Bhargava, V., Danes, S. M., Haynes, G., \& Brewton, K. E. (2010). Factors associated with long-term survival of family businesses: Duration analysis. Journal of Family and Economic Issues, 31(4), 442-457. https://dx.doi.org/10.1007/s10834-010-9232-1.

Stemler, S. (2001). An overview of content analysis. Practical Assessment, Research \& Evaluation, 7(17), 1-6.

Van Praag, C. M. (2003). Business survival and success of young small business owners. Small Business Economics, 21(1), 1-17. https://dx.doi.org/10.2139/ssrn.289202.

Villalonga, B., \& Amit, R. (2006). How do family ownership, control and management affect firm value? Journal of Financial Economics, 80(2), 385417. https://doi.org/10.1016/j.jineco.2004.12.005. 
Winter, M., Danes, S. M., Koh, S. K., Fredericks, K., \& Paul, J. J. (2004). Tracing family businesses and their owners over time: Panel attrition, manager departure and business demise. Journal of Business Venturing, 19(4), 535-559. https://dx.doi.org/10.1016/s08839026(03)00061-2.

World Bank. (2000). Sri Lanka: Recapturing missed opportunities. South Asia Region: Poverty reduction and Economic Management Unit.

Yin, R. K. (1994). Case Study Research: Design and Methods (2nd ed.). Thousand Oaks, CA: Sage Publications.
Ravindra Hewa Kuruppuge

Tomas Bata University in Zlin

Faculty of Management and Economics Department of Management and Marketing Czech Republic kuruppuge@yahoo.com

Assoc. Prof. Ales Gregar Tomas Bata University in Zlin Faculty of Management and Economics Department of Management and Marketing Czech Republic gregar@fame.utb.cz 


\section{Abstract}

\section{SURVIVAL AND LONGEVITY OF FAMILY BUSINESSES: A CASE OF EASTERN BUSINESS CULTURE}

\section{Ravindra Hewa Kuruppuge, Ales Gregar}

The main objective of this study is to understand how Sri Lankan family businesses' survive over the long term, across generations. Even though previous studies on Western business culture have adequately conceptualized operations family businesses, a huge knowledge vacuum and/or several inconsistencies are shown in Eastern business culture in case of survival and longevity of family businesses. Studies from both cultures commonly affirm that family businesses outperform over non-family firms in the short run. Similarly, most studies from Western business culture assure that family businesses are suffering from business survival problem in the long run. Contradicting to this research finding emerged in Western business culture, most Sri Lankan family businesses are reported surviving over generation from the inception. As a result, a requirement of an academic analysis of Sri Lanka family businesses has emerged. Twenty two interviews from twelve family businesses (cases) facilitated an understanding of how family members become dedicated partners of the business and contribute to its survival. Respondents were either managers or owners. Purposive sampling techniques facilitated to select respondents from respective cases. Interviews indicated that education and business challenges motivate family members to remain strongly engaged in the business, as do familial bonds and the subsequent tacit knowledge. Further, respondents revealed the interdependence of business success and the personal success of family members. Therefore, family businesses in the context of Sri Lankan business culture have experienced above-average durations of business survival in comparison to Western business culture.

Key Words: Family business, family involvement, business survival, business success, eastern business culture, western business culture, Sri Lanka.

JEL Classification: M10.

DOI: $10.15240 / t u l / 001 / 2018-4-011$ 